\title{
A Comparison of Geochronology Methods Applied to Kimberlites and Related Rocks from the Karelian Craton, Finland
}

\author{
David Phillips ${ }^{1}$, Darwin Zhong ${ }^{1}$, Erin L. Matchan ${ }^{1}$, Roland Maas ${ }^{1}$, Henrietta Farr ${ }^{1}$, \\ Hugh O'Brien ${ }^{2}$ and Andrea Giuliani ${ }^{1}$ \\ ${ }^{1}$ The University of Melbourne, Parkville, Australia,dphillip@unimelb.edu.au. \\ ${ }^{2}$ Geological Survey of Finland, Bentonimiehenkuja, Finland, hugh.obrien@gtk.fi.
}

\section{Introduction}

A range of geochronology techniques have been applied to kimberlites and related rocks, including the $\mathrm{Rb}-\mathrm{Sr}$ phlogopite, U-Pb perovskite, U- $\mathrm{Pb}$ zircon, ${ }^{40} \mathrm{Ar} /{ }^{39} \mathrm{Ar}$ phlogopite and Fission Track apatite methods. These approaches all have specific advantages and disadvantages, with the Rb-Sr phlogopite and $\mathrm{U}-\mathrm{Pb}$ perovskite methods being the most commonly used for kimberlite geochronology.

In this study, we compare the $\mathrm{Rb}-\mathrm{Sr}$ phlogopite, $\mathrm{U}-\mathrm{Pb}$ perovskite and ${ }^{40} \mathrm{Ar} /{ }^{39} \mathrm{Ar}$ phlogopite/kinoshitalite dating methods, applied to kimberlites and orangeites from the Karelian craton, Finland. This region includes the Kaavi-Kuopio Group I kimberlite province, located along the southwestern margin of the craton, the Kuusamo Group I kimberlites in the north-central part of the craton, and orangeites and related alkaline rocks of the Lentiira-Kuhmo-Kostomuksha area in the centre of the craton straddling the eastern Finland - Russia border.

\section{Previous Work}

Previously published ${ }^{206} \mathrm{U} /{ }^{238} \mathrm{~Pb}$ perovskite ages for the Kuusamo Group I Kattaisenvaara and Kalettomanpuro kimberlites are $759 \pm 15 \mathrm{Ma}$ and $756.8 \pm 2.1 \mathrm{Ma}$, respectively (O'Brien and Bradley 2008). ${ }^{206} \mathrm{U} /{ }^{238} \mathrm{~Pb}$ perovskite results for the Kaavi-Kuopia kimberlites give an age range of $589-626$ $\mathrm{Ma}$ (O'Brien et al. 2005). ${ }^{40} \mathrm{Ar}{ }^{39} \mathrm{Ar}$ analyses of phlogopite from the Seitaperä (Pipe 16, two samples) and Lentiira orangeites (Lentiira-Kuhmo cluster) yielded weighted mean ages of $1202 \pm 3 \mathrm{Ma}, 1199 \pm$ $3 \mathrm{Ma}$ and $1204 \pm 4 \mathrm{Ma}$, respectively (O'Brien et al. 2007). These results are broadly similar to $\mathrm{Rb}-\mathrm{Sr}$ data reported for orangeite samples from the Kostomuksha cluster (Belyatsii et al. 1997; Nikitina et al. 1999), which give a recalculated age of $1232 \pm 10 \mathrm{Ma}(2 \sigma ; \mathrm{MSWD}=35)$ (O'Brien et al. 2007).

\section{Methods}

Handpicked phlogopite and kinoshitalite micas were washed in water, $2 \mathrm{M} \mathrm{HCl}$, and dissolved in $\mathrm{HF}-$ $\mathrm{HNO}_{3}$. Sample solutions were equilibrated with a ${ }^{85} \mathrm{Rb}-{ }^{84} \mathrm{Sr}$ tracer, with $\mathrm{Rb}$ and $\mathrm{Sr}$ extracted on Eichrom $\mathrm{Sr}$ resin and cation resin columns. Isotopic analyses were carried out on a Nu Plasma MC-ICPMS (University of Melbourne). ${ }^{87} \mathrm{Rb} /{ }^{86} \mathrm{Sr}$ ratios determined by isotope dilution have an external precision of $\pm 0.5 \%(2 \sigma)$. Isochron ages were calculated using the ISOPLOT software from the Berkeley Geochronology Centre (www.bgc.org.au). The decay constant of ${ }^{87} \mathrm{Rb}$ is $1.397 \mathrm{E}-11 / \mathrm{yr}$.

Phlogopite and kinoshitalite grains were irradiated in the Oregon State University reactor, together with the monitor Fish Canyon Tuff sanidine (28.126 Ma; Phillips et al. 2017). Single grain ${ }^{40} \mathrm{Ar}{ }^{39} \mathrm{Ar}$ stepheating analyses were conducted on a multi-collector ARGUSVI mass spectrometer (University of Melbourne). Ages were calculated using the atmospheric ration of $298.56 \pm 0.31$ (Lee et al. 2016) and the decay constants of Steiger and Jäger (1977). Plateau ages were calculated using ISOPLOT.

\section{Results}

$\mathrm{Rb}-\mathrm{Sr}$ and ${ }^{40} \mathrm{Ar} /{ }^{39} \mathrm{Ar}$ analyses of phlogopite and kinoshitalite from representative samples of Kuusamo kimberlites produced indistinguishable ages of $747 \pm 4 \mathrm{Ma}$ and $747.8 \pm 1.0 \mathrm{Ma}(2 \sigma)$, respectively (Figs. $1,2)$, broadly similar to previous $\mathrm{U}-\mathrm{Pb}$ perovskite results from the same localities. 
$\mathrm{Rb}$-Sr analysis of three leach aliquots from a Kostomoksha orangeite dyke (KOS OL) give an isochron age of $1180 \pm 5 \mathrm{Ma}$ (Fig. 1). ${ }^{40} \mathrm{Ar}{ }^{39} \mathrm{Ar}$ analyses of single phlogopite grains from the same sample produced slightly discordant age spectra, with most ages in the range $1200-1210 \mathrm{Ma} .{ }^{40} \mathrm{Ar} /{ }^{39} \mathrm{Ar}$ analyes of phlogopite from other orangeites in the nearby Lentiira-Kuhmo cluster produced more consistent results, although only one sample produced a plateau age $-1204.4 \pm 1.2 \mathrm{Ma}(2 \sigma)$ (Fig. 3). No perovskite was recovered from the orangeite localities.

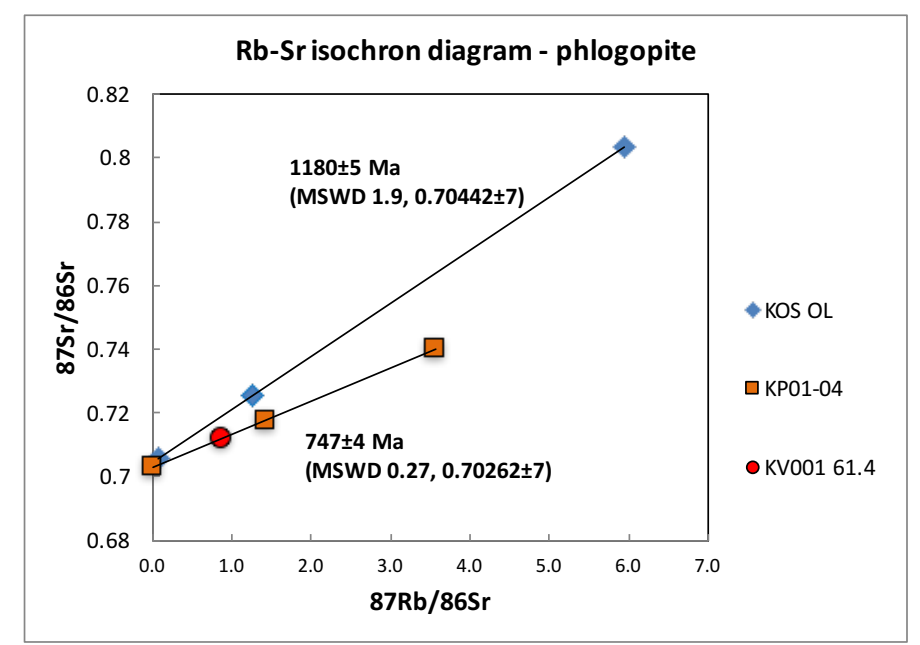

Figure 1. $\mathrm{Rb}-\mathrm{Sr}$ isochron plots for leached separates of kinoshitalite from two Kusammo Group I kimberlite (Kalettomanpuro - sample KP01-04; Kattaisenvara - sample KV001-61.4m; orange and red symbols, respectively) and from a Kostomoksha orangeite (sample Kos-Ol; blue symbols). (uncertainties are $\pm 2 \sigma$ ).

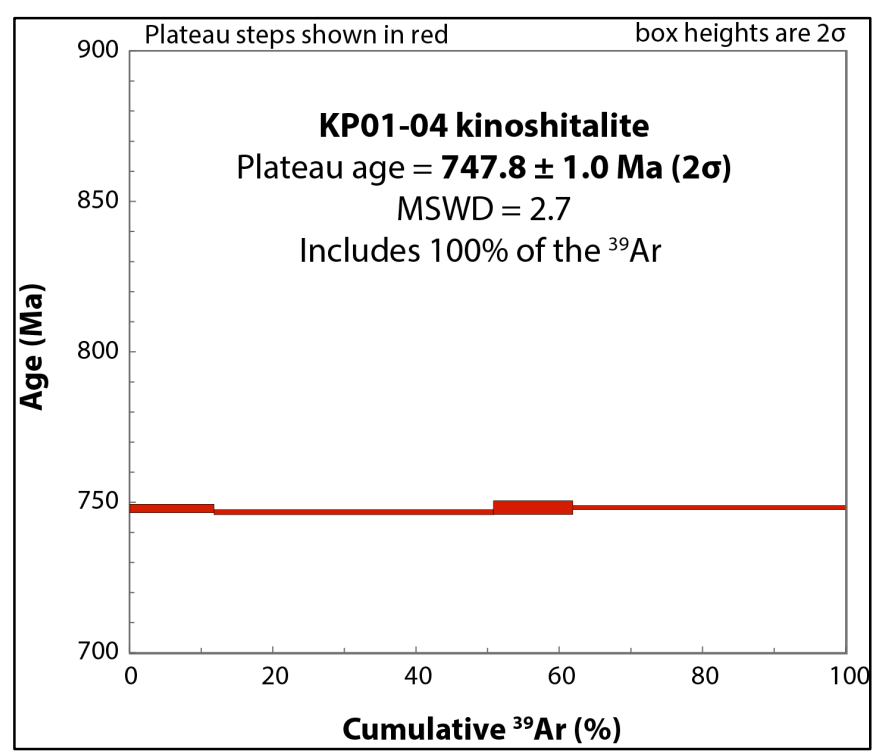

Figure 2. ${ }^{40} \mathrm{Ar} /{ }^{39} \mathrm{Ar}$ step-heating age spectrum for kinoshitalite extracted from the Kalettomanpuro Group I kimberlite (sample KP01-04), Kuusamo cluster. This sample shows a plateau age of 747.8 \pm $1.0 \mathrm{Ma}(2 \sigma)$. 


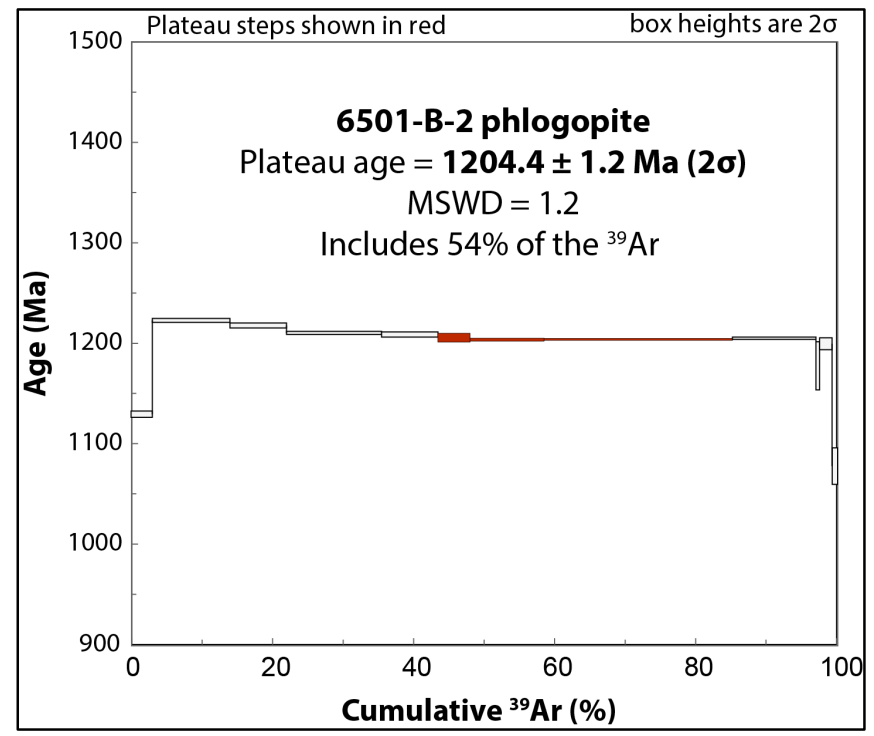

Figure 2. ${ }^{40} \mathrm{Ar} /{ }^{39} \mathrm{Ar}$ step-heating age spectrum for phlogopite extracted from the Seitaperä orangeite intrusion in the Kuhmo region (sample 6501-B-2). This age spectrum shows discordance in the low temperature steps, with the higher temperature steps yielding an plateau age of $1204.4 \pm 1.2 \mathrm{Ma}(2 \sigma)$.

\section{Discussion}

The concordance of the $\mathrm{Rb}-\mathrm{Sr}$ and ${ }^{40} \mathrm{Ar} /{ }^{39} \mathrm{Ar}$ results (748 Ma) obtained on the Kuusamo kimberlite samples provides confidence in the age of these localities. However the results are distinctly younger than the most precise ${ }^{238} \mathrm{U} /{ }^{206} \mathrm{~Pb}$ perovskite age reported for the Kuusamo cluster Kalettomanpuro kimberlite (756.8 $\pm 2.1 \mathrm{Ma}$; O'Brien and Bradley, 2008). In contrast, the $\mathrm{Rb}-\mathrm{Sr}$ and ${ }^{40} \mathrm{Ar} /{ }^{39} \mathrm{Ar}$ ages reported for the Lentiira-Kuhmo-Kostomuksha orangeites are less consistent, with Rb-Sr ages (1180 \pm $5 \mathrm{Ma}, 1232 \pm 10 \mathrm{Ma})$ bracketing ${ }^{40} \mathrm{Ar} /{ }^{39} \mathrm{Ar}$ results $(1200-1210 \mathrm{Ma})$. Unfortunately, U-Pb perovskite data could not be obtained from these localities. Although the current results provide the most precise estimates for the time of kimberlite/orangeite magmatism in Finland, this study illustrates the importance of using multiple geochronology methods for precise and accurate determination of kimberlite and orangeite emplacement events.

\section{References}

Belyatskii BV, Nikitina LP, Savva V, Levskii LK (1997) Isotopic signatures of lamproite dikes on the Eastern Baltic Shield. Geochemistry International 35: 575-579.

Lee J-Y, Marti K, Severinghaus JP, Kawamura K, Yoo H-S, Lee JB and Kim JS (2006) A redetermination of the isotopic abundances of atmospheric Ar. Geochim Cosmochim Acta 70: 6.

Nikitina LP, Levsky, LK, Lohkov, KI et al. (1999) Proterozoic alkaline-ultramafic magmatism in the eastern part of the Baltic Shield. Petrology 7: 246-266.

O'Brien HE, Peltonen P, Vartianen H (2005) Kimberlites, carbonatites, and alkaline rocks. In: Lehtinen, M., et al (Ed). Precambrian Geology of Finland-Key to the Evolution of the Fennoscandian Shield. Developments in Precambrian Geology 14. Elsevier, Amsterdam: pp. 605-644.

O'Brien H, Phillips D, Spencer R (2007) Isotopic ages of Lentiira-Kuhmo-Kostomuksha olivine lamproite- group II, kimberlites. Bull Geol Soc Finland 79: 203-215.

O’Brien H, Bradley J (2008) New kimberlite discoveries in Kuusamo, northern Finland. In: Extended Abstracts, Proc. 9th International Kimberlite Conf. Frankfurt. 9IKC-A-00346: 3.

Phillips D., Matchan E.L., Honda M., Kuiper K.F. (2017) Astronomical calibration of ${ }^{40} \mathrm{Ar} r{ }^{39} \mathrm{Ar}$ reference minerals using high-precision, multi-collector (ARGUSVI) mass spectrometry. Geochim Cosmochim Acta 196: 351-369.

Steiger R., Jäger E. (1977) Subcommission on geochronology: convention on the use of decay constants in geo-and cosmochronology. Earth Planet Sci Lett 36: 359-362. 